\title{
High Nitrogen Fertilization Modulates Morpho-Physiological Responses, Yield, and Water Productivity of Lowland Rice under Deficit Irrigation
}

\author{
Nasr M. Abdou ${ }^{1}$, Mohamed A. Abdel-Razek ${ }^{1}$, Shimaa A. Abd El-Mageed ${ }^{2}$, Wael M. Semida ${ }^{3, *(D)}$, \\ Ahmed A. A. Leilah ${ }^{4}$, Taia A. Abd El-Mageed ${ }^{1}{ }^{(D)}$, Esmat F. Ali ${ }^{5}$,, Ali Majrashi ${ }^{5}$ and Mohamed O. A. Rady ${ }^{2}$ \\ 1 Soil and Water Department, Faculty of Agriculture, Fayoum University, Fayoum 63514, Egypt; \\ nma02@fayoum.edu.eg (N.M.A.); maa27@fayoum.edu.eg (M.A.A.-R.); taa00@fayoum.edu.eg (T.A.A.E.-M.) \\ 2 Agronomy Department, Faculty of Agriculture, Fayoum University, Fayoum 63514, Egypt; \\ sa1944@fayoum.edu.eg (S.A.A.E.-M.); mer00@fayoum.edu.eg (M.O.A.R.) \\ 3 Horticulture Department, Faculty of Agriculture, Fayoum University, Fayoum 63514, Egypt \\ 4 Agronomy Department, Faculty of Agriculture, Mansoura University, Mansoura 35516, Egypt; \\ ahmed_leila@mans.edu.eg \\ 5 Department of Biology, College of Science, Taif University, P.O. Box 11099, Taif 21944, Saudi Arabia; \\ a.esmat@tu.edu.sa (E.F.A.); aa.majrashi@tu.edu.sa (A.M.) \\ * Correspondence: wms00@fayoum.edu.eg; Tel.: +2-010-107-877-88
}

Citation: Abdou, N.M.;

Abdel-Razek, M.A.; Abd El-Mageed, S.A.; Semida, W.M.; Leilah, A.A.A.; Abd El-Mageed, T.A.; Ali, E.F.; Majrashi, A.; Rady, M.O.A. High Nitrogen Fertilization Modulates Morpho-Physiological Responses, Yield, and Water Productivity of Lowland Rice under Deficit Irrigation. Agronomy 2021, 11, 1291. https:// doi.org/10.3390/agronomy11071291

Academic Editors: Umberto Anastasi and Aurelio Scavo

Received: 10 May 2021

Accepted: 23 June 2021

Published: 25 June 2021

Publisher's Note: MDPI stays neutral with regard to jurisdictional claims in published maps and institutional affiliations.

Copyright: (C) 2021 by the authors Licensee MDPI, Basel, Switzerland. This article is an open access article distributed under the terms and conditions of the Creative Commons Attribution (CC BY) license (https:// creativecommons.org/licenses/by/ $4.0 /)$

\begin{abstract}
Sustainability of rice production under flooding conditions has been challenged by water shortage and food demand. Applying higher nitrogen fertilization could be a practical solution to alleviate the deleterious effects of water stress on lowland rice (Oryza sativa L.) in semi-arid conditions. For this purpose, field experiments were conducted during the summer of 2017 and 2018 seasons. These trials were conducted as split-split based on randomized complete blocks design with soil moisture regimes at three levels $(120,100$ and $80 \%$ of crop evapotranspiration (ETc), nitrogen fertilizers at two levels $\left(\mathrm{N}_{1}-165\right.$ and $\left.\mathrm{N}_{2}-200 \mathrm{~kg} \mathrm{~N} \mathrm{ha}^{-1}\right)$ and three lowland Egyptian rice varieties $\left[\mathrm{V}_{1}\left(\mathrm{Giza}_{178}\right)\right.$, $\mathrm{V}_{2}\left(\mathrm{Giza}_{177}\right)$ and $\left.\mathrm{V}_{3}\left(\mathrm{Sakha}_{104}\right)\right]$ using three replications. For all varieties, growth (plant height, tillers No, effective tillers no), water status ((relative water content RWC, and membrane stability index, MSI), physiological responses (chlorophyll fluorescence, Relative chlorophyll content (SPAD), and yield were significantly increased with higher addition of nitrogen fertilizer under all water regimes. Variety $\mathrm{V}_{1}$ produced the highest grain yield compared to other varieties and the increases were $38 \%$ and $15 \%$ compared with $\mathrm{V}_{2}$ and $\mathrm{V}_{3}$, respectively. Increasing nitrogen up to $200 \mathrm{~kg} \mathrm{~N} \mathrm{ha}^{-1}\left(\mathrm{~N}_{2}\right)$ resulted in an increase in grain and straw yields by 12.7 and $18.2 \%$, respectively, compared with $\mathrm{N}_{1}$. The highest irrigation water productivity (IWP) was recorded under $\mathrm{I}_{2}\left(0.89 \mathrm{~kg} \mathrm{~m}^{-3}\right)$ compared to $\left(0.83 \mathrm{~kg} \mathrm{~m}^{-3}\right)$ and $\left(0.82 \mathrm{~kg} \mathrm{~m}^{-3}\right)$ for $\mathrm{I}_{1}$ and $\mathrm{I}_{3}$, respectively. Therefore, the new applied agromanagement practice (deficit irrigation and higher nitrogen fertilizer) effectively saved irrigation water input by $50-60 \%$ when compared with the traditional cultivation method (flooding system). Hence, the new proposed innovative method for rice cultivation could be a promising strategy for enhancing the sustainability of rice production under water shortage conditions.
\end{abstract}

Keywords: Oryza sativa; drought stress; chlorophyll fluorescence; varieties; grain yield and water productivity

\section{Introduction}

Rice (Oryza sativa L.) is a staple food crop for about half of the world's population and ranks 2nd in production after wheat [1,2]. Globally, in 2018, the productivity of rice approximately amounted to 700 million tons, which was produced from 167 million hectares, by an average grain yield of 4.2 tons per hectare [2]. Rice (Oryza sativa L.) is being cultivated in various agro-ecosystems: irrigated rice, rainfed lowland rice, upland rice, and flood-prone rice. More than $75 \%$ of rice production is supplied by irrigated 
lowland rice [3]. Generally, rice has been grown under flooded conditions, maintaining a continuous water depth by 5-10 cm [4]. Under flooded conditions, a large amount of irrigation water supply is required, which is not only used for the growth and development of rice plants but also as a management technique during rice cultivation $[5,6]$. In a puddled rice field, the consumption of water depends on the rates of evaporation, transpiration, and water losses by percolation, seepage, and surface runoff. The irrigation water demand for rice crops under the traditional flooded system is more than $20,000 \mathrm{~m}^{3} \mathrm{ha}^{-1}$ which is more than 3-4 times that of its biological needs from water, which ranges between 6000-8000 $\mathrm{m}^{3} \mathrm{ha}^{-1}$ [7].

With increasing water scarcity, rapid population growth, increased urbanization, and the expected potential climate change, the sustainability, food production, and ecosystem services of rice fields are threatened [7-10]. It is estimated that, by 2025, 15-20 million ha of irrigated rice will suffer from some degree of water scarcity. Rice production in the Nile Delta of Egypt consumes about 11 billion $\mathrm{m}^{3}$ of irrigation water which represents about $20 \%$ of the whole quantity of irrigation water used in agriculture ( 55.5 billion $^{3} /$ year). In addition, many studies conducted in Egypt concluded that the total seasonal water input to rice under continuous flooding ranges between $16,190-21,428 \mathrm{~m}^{3} \mathrm{ha}^{-1}$ [11]. Therefore, Egypt's policymakers annually reduce the allotted area for rice cultivation, which has decreased by $59 \%$ from 745,000 ha to 304,080 ha during the past ten years (2008-2018) [2].

Therefore, good water governance should be adopted to develop socially acceptable, economically viable and environmentally sustainable novel rice-based systems that tend to reduce water losses and enhance crop productivity challenged by high evaporative demand and severe shortages of water supply. Hence, cultivating rice aerobically in non-puddled and non-saturated soils under water-saving irrigation technique as deficit irrigation could be a promising water-saving strategy to cope with water scarcity.

The application of irrigation water below the ET demand is termed deficit irrigation, aiming at optimization in economic output when water is very limited [12]. Plants under deficit irrigation receive a lower amount of irrigation water than their full water requirements either at specific crop growth stages or during the total cultivation period [12]. Consequently, under deficit irrigation technique, plants are subjected to water stress to some extent $[13,14]$.

However, rice is very sensitive to water stress. Water stress negatively affects the growth and productivity of crops $[15,16]$. Physiological functioning in rice plants [17] viz root length density, root moisture extraction, the rate of apical development, canopy size, leaf elongation rate, leaf rolling, transpiration rate, relative water content, biomass production, spikelet number, spikelet sterility, panicle development, grain size and grain yield $[17,18]$ may be drastically reduced due to water stress, if it occurs during vegetative or reproductive stages of rice, depending upon the stress severity and cultivar tolerance.

However, optimal application of nitrogen also plays a valuable role in combating drought [19]. Nitrogen (N) is considered a key component of many organic compounds. Nitrogen is one of the most essential nutrient elements for rice growth and metabolic processes [20,21]. Nitrogen represents a vital role in improving yield production and enhancing the photosynthetic activity especially during the grain filling stage of rice crops. Hence, the efficient use and nitrogen management respecting crop production is an urgent case for maximizing crop productivity, environmental safety with increasing economic returns [22,23] also concluded that increasing nitrogen supplying dose up to $144 \mathrm{~kg} \mathrm{~N}^{-1}$ improved and significantly affected plant growth, grain yield and yield components. Ref. Ref. [24] reported that increasing nitrogen application rates from 120 to $190 \mathrm{~kg} \mathrm{~N}^{-1}$ significantly improved plant height, panicle length, filled grains by panicle and grain yields. Ref. Ref. [25] reported that the inoculation with G. diazotrophicus Pal5 strain was alleviated deleterious effects of drought stress on rice plants, and improved biomass and grain yield. In addition, [26] noted that there were significant increases in plant growth traits, yield parameters and grain yield due to increasing nitrogen supplying rate of 100, 200 and $300 \mathrm{~kg}$ $\mathrm{N} \mathrm{ha}{ }^{-1}$. Ref. Ref. [27] observed an interaction between soil moisture deficit and $\mathrm{N}$ supply 
rates on the activity of photosynthesis and transpiration processes in rice. Application of $\mathrm{N}$ fertilizer resulted in a significant increase in grain yield of rainfed-lowland rice under water deficit, where observed the optimal timing of $\mathrm{N}$ application for continuously irrigated rice was when the rice was exposed to moderate water deficit before flowering [28]. The absorption and utilization of water and nitrogen nutrition are two coupled physiological processes $[29,30]$. Supplying plants with $\mathrm{N}$ can increase drought resistance by increasing root hydraulic conductivity (Lpr) through increased abscisic acid (ABA) and aquaporin expression [31-34].

Therefore, the current study hypothesized that exogenous application of $\mathrm{N}$-fertilizer may positively affect the rice performance, irrigation water productivity, chlorophyll fluorescence, water status as well as yield of some drought-stressed lowland rice varieties. Accordingly, the recent investigation was conducted to evaluate the effect of new applied water and nutrition environment on water-saving capacity and productivity of some lowland rice varieties under water-scarce conditions in arid and semi-arid regions.

\section{Materials and Methods}

\subsection{Experimental Design, Treatments, and Cultural Practices}

The current investigation was conducted at the experimental station farm of Faculty of Agriculture, Fayoum University, Egypt, (30 56 _N latitude, $75^{\circ} 52$ _longitude). The site is described by arid climate type, hot in summer. The meteorological data in Table 1 show that the highest mean values of maximum temperature, minimum temperature and relative humidity $\%$ by $40.4{ }^{\circ} \mathrm{C}, 26{ }^{\circ} \mathrm{C}$ and $45 \%$, respectively, were recorded during August. The maximum pan evaporation rate $\left(\mathrm{mm} \mathrm{day}^{-1}\right) 7.5$ occurred in June month and decreased to its lowest value 5.3 in September during the two successive seasons of rice cultivation (2017-2018).

Table 1. Meteorological data recorded at Meteorological observatory of Fayoum governorate, during crop growing seasons of 2017 and 2018.

\begin{tabular}{|c|c|c|c|c|c|c|c|}
\hline \multirow{2}{*}{ Month } & \multirow{2}{*}{ Year } & \multicolumn{3}{|c|}{ Temperature ${ }^{\circ} \mathrm{C}$} & \multirow{2}{*}{$\begin{array}{c}\text { Relative } \\
\text { Humidity } \\
(\%)\end{array}$} & \multirow{2}{*}{$\begin{array}{l}\text { Wind } \\
\text { Speed } \\
\left(\mathrm{m} \mathrm{s}^{-1}\right)\end{array}$} & \multirow{2}{*}{$\begin{array}{c}\text { Pan } \\
\text { Evaporation } \\
\left(\mathrm{mm} \mathrm{day}{ }^{-1}\right)\end{array}$} \\
\hline & & Max. & Min. & Mean & & & \\
\hline \multirow{2}{*}{ May } & 2017 & 35.2 & 20.9 & 28.1 & 39.6 & 4.2 & 6.5 \\
\hline & 2018 & 37.3 & 22.6 & 29.9 & 41.0 & 3.9 & 6.6 \\
\hline \multirow{2}{*}{ June } & 2017 & 36.0 & 21.7 & 28.9 & 42.1 & 5.2 & 7.3 \\
\hline & 2018 & 40.3 & 24.4 & 32.3 & 38.6 & 5.0 & 7.5 \\
\hline \multirow{2}{*}{ July } & 2017 & 37.0 & 21.8 & 29.4 & 35.5 & 4.0 & 6.9 \\
\hline & 2018 & 39.3 & 23.9 & 31.6 & 37.8 & 3.7 & 6.9 \\
\hline \multirow{2}{*}{ August } & 2017 & 40.4 & 26.0 & 33.2 & 36.9 & 1.9 & 6.2 \\
\hline & 2018 & 36.4 & 23.0 & 29.6 & 45.2 & 3.7 & 6.3 \\
\hline \multirow{2}{*}{ September } & 2017 & 38.3 & 13.8 & 31.0 & 36.6 & 2.0 & 5.5 \\
\hline & 2018 & 35.3 & 21.0 & 28.0 & 44.3 & 3.5 & 5.3 \\
\hline
\end{tabular}

Max, and Min are maximum, and minimum temperatures, respectively.

\subsection{Soil Characteristics}

Table 2 shows that the soil is clay-textured. Soil moisture content \% (at 0.33 bar and at 15 bar), available water $\%$, bulk density $\left(\mathrm{g} \mathrm{cm}^{-3}\right)$ and saturated hydraulic conductivity $\left(\mathrm{cm} \mathrm{h}^{-1}\right)$ were determined at the surface soil layer $(0-0.25 \mathrm{~m})$ and amounted to 34.33, 14.60, $19.73,1.40$ and 1.2, respectively, and by 32.19, 13.06, 19.13, 1.36 and 0.9 , respectively, a subsurface $(0.25-0.5 \mathrm{~m})$.

According to the data represented in Table 2, organic matter content was $1.2 \%$, available nitrogen-0.04\%, available phosphorus $\left(\mathrm{mg} \mathrm{kg}^{-1}\right.$ soil) 5.84 and available potassium $61.9\left(\mathrm{mg} \mathrm{kg}^{-1}\right.$ soil), ECe, $\left(\mathrm{dS} \cdot \mathrm{m}^{-1}\right), \mathrm{pH}, \mathrm{CEC}\left(\mathrm{cmol}_{\mathrm{e}} \mathrm{kg}^{-1}\right)$ and $\mathrm{CaCO}_{3}(\%)$ were measured and amounted 2.62, 7.76, 14.10 and 4.81, respectively. Soil physical and chemical properties were determined according to $[35,36]$. 
Table 2. Some initial physical and chemical properties of the experimental soil.

\begin{tabular}{|c|c|c|c|c|c|c|c|c|c|}
\hline \multicolumn{10}{|c|}{ Physical Properties } \\
\hline \multirow[b]{2}{*}{$\begin{array}{l}\text { Layer } \\
(\mathrm{cm})\end{array}$} & \multicolumn{4}{|c|}{ Particle Size Distribution } & \multirow{2}{*}{$\begin{array}{c}\text { Bulk } \\
\text { Density } \\
\left(\mathrm{g} \mathrm{cm}^{-3}\right)\end{array}$} & \multirow[b]{2}{*}{$\begin{array}{c}\mathrm{K}_{\mathrm{sat}} \\
\mathrm{Cm} \mathrm{h}^{-1}\end{array}$} & \multirow[b]{2}{*}{$\begin{array}{l}\text { FC } \\
(\%)\end{array}$} & \multirow[b]{2}{*}{$\begin{array}{l}\text { WP } \\
(\%)\end{array}$} & \multirow[b]{2}{*}{$\begin{array}{l}\text { AW } \\
(\%)\end{array}$} \\
\hline & $\begin{array}{c}\text { Sand } \\
\%\end{array}$ & $\begin{array}{c}\text { Silt } \\
\%\end{array}$ & $\underset{\%}{\text { Clay }}$ & $\begin{array}{c}\text { Texture } \\
\text { Class }\end{array}$ & & & & & \\
\hline $0-25$ & 10.00 & 20.00 & 70.00 & Clay & 1.40 & 1.20 & 34.33 & 19.73 & 14.60 \\
\hline $25-50$ & 7.00 & 21.00 & 72.00 & Clay & 1.36 & 0.90 & 32.19 & 19.13 & 13.06 \\
\hline \multicolumn{10}{|c|}{ Physical Properties } \\
\hline & $\mathrm{pH}$ & $\begin{array}{c}\mathrm{ECe} \\
\left(\mathrm{dS} \cdot \mathrm{m}^{-1}\right)\end{array}$ & $\begin{array}{c}\text { CEC } \\
\left(\mathrm{cmole} \mathrm{kg}^{-1}\right)\end{array}$ & $\begin{array}{c}\mathrm{CaCO}_{3} \\
(\%)\end{array}$ & $\begin{array}{c}\text { Organic } \\
\text { Matter (\%) }\end{array}$ & N (\%) & \multicolumn{2}{|c|}{$\begin{array}{c}P \\
\left(\mathrm{mg} \mathrm{kg}^{-1} \text { soil }\right)\end{array}$} & $\begin{array}{c}\mathrm{K} \\
\left(\mathrm{mg} \mathrm{kg}^{-1} \text { soil) }\right.\end{array}$ \\
\hline $0-25$ & 7.76 & 2.62 & 14.10 & 4.81 & 1.20 & 0.04 & \multicolumn{2}{|c|}{5.8} & 61.90 \\
\hline $25-50$ & 7.78 & 2.52 & 14.00 & 4.76 & 1.10 & 0.04 & \multicolumn{2}{|c|}{5.6} & 60.00 \\
\hline
\end{tabular}

$\mathrm{K}_{\mathrm{sat}}=$ Hydraulic conductivity, $\mathrm{FC}=$ Field capacity, $\mathrm{WP}=$ wilting point, and $\mathrm{AW}=$ Available water.

\subsection{Experimental Layout and Treatments}

Seeds of the three studied lowland rice varieties [ $\mathrm{V}_{1}$ (Giza-178), $\mathrm{V}_{2}$ (Giza-177) and $\mathrm{V}_{3}$ (Sakha-104)] were sown manually on 16 May 2017 and 10 May 2018 in rows with seed rate $130 \mathrm{~kg} \mathrm{~h}^{-1}$ with rows spaced distance $0.25 \mathrm{~m}$. The characteristics of the tested rice varieties were reported by [37] as follows:

$V_{1}$ (Giza-178): Pedigree (Giza175/Milyang 49), Properties (Indica/Japonica type-tolerant to drought-medium maturing - high yield), grain yield $\left(10 \mathrm{tha}^{-1}\right)$ growth period (135 days) $V_{2}$ (Giza-177): Pedigree (Giza 171/Yomjo No. 1//PiNo.4,) Japonica type-sensitive to drought-short stature-early duration-, grain yield $\left(9 \mathrm{t} \mathrm{ha}^{-1}\right)$ and the growth period (125 days)

$\mathrm{V}_{3}$ (Sakha-104): Pedigree (GZ4096-8-1/GZ4100-9-1), Properties (Japonica type-sensitive to drought-), grain yield (10 tha $\left.{ }^{-1}\right)$ growth period (135 days)

Each sub-subplot (experimental unit) involved 5 rows. Agronomic practices for crop management viz fertilizers, pesticides and herbicides applications were implemented according to the recommended practices described by [38]. Fertilizers were manually broadcast then incorporated within the basal application ( $35 \mathrm{~kg} P$ and $50 \mathrm{~kg} \mathrm{~K}$ per hectare). The experiments were conducted in a randomized complete block design (Split-split Plot) in three replicates including three factors. Using a surface irrigation system, three different irrigation regimes as follows: $\mathrm{I}_{1}\left(120 \%\right.$ of ETc), $\mathrm{I}_{2}\left(100 \%\right.$ of ETc) and $\mathrm{I}_{3}(80 \%$ of ETc) were applied and allocated to the main plots and two $\mathrm{N}$ fertilization levels $\mathrm{N}_{1}(100 \%$ of recommended dose (RD) by $165 \mathrm{~kg} \mathrm{~N} \mathrm{ha}^{-1}$ ) and $\mathrm{N}_{2}\left(125 \%\right.$ of $\mathrm{RD}$ by $200 \mathrm{~kg} \mathrm{~N} \mathrm{ha}^{-1}$ ), were broadcasted in three equal splits and added at basal, mid-tillering and panicle initiation of rice developing stages and allocated to the sub main plots, where the three lowland rice varieties seeded and allocated to sub-sub main plots. The total experimental area specified for each year was $1134 \mathrm{~m}^{2}$ divided into 54 experimental plots of $21 \mathrm{~m}^{2}$ for each. To protect against irrigation and nitrogen fertilizer treatment effects, three meters were utilized to isolate the experimental units.

\subsection{Irrigation Water Requirements (IWR)}

The IWR was determined according to [39] equation as follows:

$$
\mathrm{IWR}=\frac{\mathrm{A} \times \mathrm{ETc} \times \mathrm{Ii}}{\mathrm{Ea} \times 1000}
$$

where, IWR: irrigation water requirements $\left(\mathrm{m}^{3}\right)$, A: plot area $\left(\mathrm{m}^{2}\right)$, ETc: water consumptive use $\left(\mathrm{mm} \mathrm{day}^{-1}\right)$, Ii: intervals between irrigation (day), and Ea: application efficiency $(\%)$. 
To convey water for each plot plastic pipe (spiles) of 2 inch diameter was used, and the amount of water delivered through a plastic pipe was calculated according to [40].

$$
\mathrm{Q}=\mathrm{CA} \sqrt{2 \mathrm{gh}} \times 10^{-3}
$$

where: $\mathrm{Q}$ is the discharge of irrigation water $\left(\mathrm{m}^{3}\right), \mathrm{C}$ is the coefficient of discharge, $\mathrm{A}$ is a cross-sectional area of irrigation pipe $\left(\mathrm{cm}^{2}\right), \mathrm{g}$ is gravity acceleration $\left(\mathrm{cm} \mathrm{s}^{-2}\right)$ and $\mathrm{h}$ is the average of the effective head of water $(\mathrm{cm})$ above the pipe.

ETc: Water consumptive use $\left(\mathrm{mm} \mathrm{day}^{-1}\right)$

$$
\mathrm{ET}_{\mathrm{c}}=\mathrm{ET}_{0} \times \mathrm{K}_{\mathrm{c}}
$$

where: ETc: crop water consumption $\left(\mathrm{mm} \mathrm{d}^{-1}\right), \mathrm{ET}_{0}$ is the reference evapotranspiration $\left(\mathrm{mm} \mathrm{d}^{-1}\right)$, and Kc: crop coefficient.

$$
\mathrm{ET}_{0}=\mathrm{E}_{\text {pan }} \times \mathrm{K}_{\mathrm{p}}
$$

where $E_{p a n}$ is the evaporation from a class $A\left(\mathrm{~mm} \mathrm{day}^{-1}\right)$ and $K_{p}$ : is the pan coefficient.

\subsection{Plant Physiological Measurements}

2.5.1. Chlorophyll a Fluorescence (Fv/Fm) and Performance Index (PI) Values

Chlorophyll $a$ fluorescence was determined by plant efficiency analyzer, Handy PEA (Hansatech Instruments Ltd., Norfolk, UK). From each plot, ten fully expanded flag leaves were randomly selected, the leaf samples were dark-adapted for $15 \mathrm{~min}$ before being illuminated with irradiance intensity of $3000 \mu \mathrm{mol} /\left(\mathrm{m}^{2} \cdot \mathrm{s}\right)$ [41,42]. While PI was measured as reported by [43].

\subsubsection{Relative Water Content (RWC)}

Leaf samples for RWC measurement were randomly collected in the morning (8:00 to 9:00 a.m.). RWC was estimated according to the method described by [44].

$$
\operatorname{RWC}(\%)=(F W-D W) \times 100 /(T W-D W)
$$

where: FW: Fresh weight was measured within two hours after excision of leaves. Turgid weight (TW) was computed by soaking leaves in distilled water and left at room temperature for (16-18 h) then rapidly and carefully blotted dry by tissue paper to determine turgid weight. The small leaf pieces were later oven-dried for $48 \mathrm{~h}$ at $70{ }^{\circ} \mathrm{C}$ to estimate the dry weight (DW).

\subsubsection{Relative Chlorophyll Content (SPAD)}

The SPAD meter (SPAD502, KONICAMINOLTA. Inc., Tokyo, Japan) was used to estimate the relative chlorophyll content of the rice.

\subsubsection{Membrane Stability Index (MSI \%)}

The (MSI \%) was measured by the method described by [45]. The small leaf strips $(0.2 \mathrm{~g})$ of equal size were prepared and taken in two sets of test tubes containing $10 \mathrm{~mL}$ of distilled water. The test tubes arranged in one set were maintained at $40{ }^{\circ} \mathrm{C}$ in a water bath for $30 \mathrm{~min}$ then the ECe of the water covering the leaf samples was estimated $\left(\mathrm{C}_{1}\right)$. While the test tubes of the other set were incubated in a bath of boiling water at $100{ }^{\circ} \mathrm{C}$ for $15 \mathrm{~min}$ then measured ECe $\left(C_{2}\right)$. The MSI was computed: MSI $=\left[1-\left(C_{1} / C_{2}\right)\right] \times 100$.

\subsection{Growth, Yield and Yield Components Measurements}

All the studied three rice varieties were harvested after 135 days from the sowing date. From each plot, ten plants were selected randomly to determine the plant growth and yield components parameters, i.e., tillers and productive tillers number, plant height 
(from ground level to the tip of panicle, was measured by meter-scale), length and weight of panicle, number and weight of grains per panicle and 100-grain weight. The grain and straw yield were measured by using digital balance from all plants collected from $1 \mathrm{~m}^{2}$ sampling area.

\subsection{Grain N Content}

Digestion process was performed for the dried grain samples with a mixture consisting of perchloric and nitric acids (at 1:3, $v / v$, respectively). Using the previous digestion solution, an assessment of $\mathrm{N}$ content was performed. Determination of $\mathrm{N}$ was performed using the micro-Kjeldahl apparatus (Ningbo Medical Instruments Co., Ningbo, China) following [46] methods.

\subsection{Irrigation Water Productivity (IWP) \\ IWP was determined according to [47].}

$$
\operatorname{IWP}\left(\mathrm{Kg} \mathrm{m}^{-3}\right)=\frac{\text { grain yield }\left(\mathrm{Kg} \mathrm{ha}^{-1}\right)}{\text { irrigation water applied }\left(\mathrm{m}^{3} \mathrm{ha}^{-1}\right)}
$$

Crop water productivity (CWP): was computed according to [48].

$$
\mathrm{CWP}\left(\mathrm{Kg} \mathrm{m}^{-3}\right)=\frac{\text { grain yield }\left(\mathrm{Kg} \mathrm{ha}^{-1}\right)}{\text { water consumptive }\left(\mathrm{m}^{3} \mathrm{ha}^{-1}\right)}
$$

\subsection{Statistical Analysis}

The obtained data for each variable were subjected to two-way analysis of variance (ANOVA) using GenStat statistical package (12th Ed., VSN International Ltd., Oxford, UK). In case of significant effects, the treatment means were separated using LSD test at $p \leq 0.05$ probability level.

\section{Results and Discussion}

\subsection{Rice Water Status}

Results of plant water status (RWC and MSI) in response to irrigation, nitrogen and variety are displayed in Table 3. In both seasons, the highest MSI, RWC values were recorded when rice was subjected to irrigation at $120 \%$ of ETC and received $200 \mathrm{~kg} \mathrm{~N} \mathrm{ha}^{-1}$; on the other hand, the integrative application of irrigation at $80 \%$ of ETc and plants received $165 \mathrm{~kg} \mathrm{~N} \mathrm{ha}^{-1}$ recorded the lowest values over all varieties.

Regarding the effect of varieties, data enumerated in Table 3 revealed that Giza- $178\left(\mathrm{~V}_{1}\right)$ recorded the highest MSI, RWC values while Giza-177 $\left(\mathrm{V}_{2}\right)$ gave the lowest values in both seasons. Application of $200 \mathrm{~kg} \mathrm{~N} \mathrm{ha}^{-1}$ to drought-stressed plants up to $20 \%$ compensated for this shortage of irrigation and recorded similar values to well-irrigated plants $\left(\mathrm{I}_{120 \%}\right)$ and received $165 \mathrm{~kg} \mathrm{~N} \mathrm{ha}^{-1}$. RWC and MSI declined remarkably in both $\mathrm{I}_{100 \%}$ and $\mathrm{I}_{80 \%}$ treatment compared with well-watered treatment $\left(\mathrm{I}_{120 \%}\right)[49,50]$. We found that RWC and MSI had positive relationships with IWA irrespective of nitrogen applications. The RWC and MSI values were decreased as drought increased. Interestingly, leaf RWC and MSI in higher $\mathrm{N}$ treatment were 3.2 and 5.2\% higher than that low $\mathrm{N}$ treatment, irrespective of the variety effect. In this investigation, $\mathrm{N}$-supply decreased the detrimental effects of water stress on rice plants and kept their RWC and MSI values at close levels as in well-watered plants (Table 3). In the present study, the adverse changes that occurred in the health of cell membranes under drought stress were assessed. Our results revealed that higher $\mathrm{N}$-application plays an important role in stabilizing membrane integrity and maintaining cell turgor of rice leaves under drought stress. In this respect, increases of tissue RWC and MSI as metabolically available water seems to maintain tissue health and may reflect on the metabolic processes in rice under water stress, which agrees with the results of [34,51], who 
stated that, N supply under drought stress improved RWC and MSI as well as enhanced the photosynthetic efficiency with increased grain yield of wheat plants. Our results agree with those of $[48,52]$. They reported that drought stress severely affected and reduced rice growth, photosynthesis, stomatal conductance. Ref. [53] reported drought adversely affects physiological responses of plants through a reduction in gas exchange especially stomatal conductance, photosynthetic pigments and overall crop water status.

\subsection{Leaf Physiological Traits}

For all varieties, physiological traits like relative chlorophyll content (SPAD value), chlorophyll fluorescence (Fv/Fm) and performance index (PI) were significantly improved in drought stress-treated rice plants under high $\mathrm{N}$ application (Table 3). Drought stress $(80 \%$ of ETc) reduced the values of SPAD $(18.7 \%)$, Fv $/$ Fm $(5.5 \%)$, and PI $(46.1 \%)$ as compared to plants irrigated at $120 \%$ of ETc (Table 3$)$. All physiological traits were significantly decreased under drought $[17,54]$. However, rice plants that received high N concentrations (200 $\mathrm{kg} \mathrm{ha}^{-1}$ ) significantly increased SPAD (7.3\%), Fv/Fm (3.8\%), and PI $(45.3 \%)$, as compared to low $\mathrm{N}$ concentration, over all varieties as average for both seasons. Moreover, results in Table 3 showed that the highest SPAD, Fv / Fm, and PI values were recorded in $\mathrm{Giza}_{178}\left(\mathrm{~V}_{1}\right)$, while the lowest values were recorded under $\mathrm{Giza}_{177}\left(\mathrm{~V}_{2}\right)$ for both seasons. The best results of these traits were recorded in $\mathrm{Giza}_{178}$ with application of $200 \mathrm{~kg} \mathrm{~N} \mathrm{ha}^{-1}+\mathrm{I}_{120}$ of ETc. Our results suggest that the application of high $\mathrm{N}$ concentration can mitigate the negative effects of water stress on SPAD, Fv /Fm, and PI and as a result of increasing the photosynthetic efficiency of rice plants. Similar trends were reported by $[16,55-58]$.

\subsection{Plant Growth Characteristics}

Results presented in Table 4 showed that the applied irrigation regimes, nitrogen fertilization levels and their interaction significantly affected the plant height and the number of effective tillers. Applying water stress level (I 80\%) significantly reduced plant height, tillers No, effective tillers no and panicle length by $9.45,21.54,21.12$ and $10.58 \%$ compared by control (I 120\%). Increasing the amount of the applied irrigation water and nitrogen dose at $\left(\mathrm{I}_{120} \times \mathrm{N}_{2}\right)$ treatment gave the greatest values of plant height and effective tillers. Tillers number in particular fertile tillers is considered one of the most important components of yield. The observed increase in number of fertile tillers in the current investigation might be related to the higher availability of the nitrogen element that played a vital role in cell division. On the contrary, the lowest estimation for these parameters was observed at $\left(\mathrm{I}_{80} \times \mathrm{N}_{1}\right)$ treatment. Drought stress may cause various structural and functional disruptions in reproductive organs [20]. Among the grown rice varieties $\left(\mathrm{Giza}_{178}\right)$ recorded the maximum plant height $(76.14 \mathrm{~cm})$ and effective tillers number (2.75) as compared with other varieties. The increases in both plant height and produced effective tillers under $\left(\mathrm{I}_{1} \times \mathrm{N}_{2}\right)$ treatment could be due to the availability of water and nitrogen resulting in better translocation of photosynthesis, higher cell deviation and there by favored highest yield attributes under these treatments. The obtained results were in line with [59] who observed that increasing nitrogen fertilizer resulted in drier matter accumulation. Ref. [60,61] found that the irrigation regime and $\mathrm{N}$ application significantly affected rice yield and yield traits. In addition, increasing the $\mathrm{N}$ uptake may have beneficial effects on plants grown under drought conditions, where the plant drought resistance increased with increasing $\mathrm{N}$ supply resulted in increasing root hydraulic conductivity (Lpr) through increased abscisic acid and aquaporin expression [30,31]. 


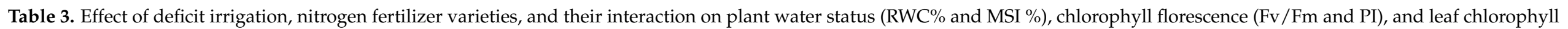

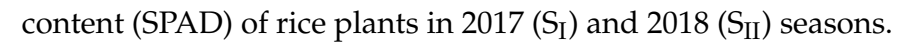

\begin{tabular}{|c|c|c|c|c|c|c|c|c|c|c|}
\hline \multirow{2}{*}{$\begin{array}{l}\text { Source of } \\
\text { Variation }\end{array}$} & \multicolumn{2}{|c|}{ RWC\% } & \multicolumn{2}{|c|}{ MSI\% } & \multicolumn{2}{|c|}{ SPAD } & \multicolumn{2}{|c|}{ Fv/Fm } & \multicolumn{2}{|c|}{ PI } \\
\hline & $S_{\text {I }}$ & $S_{\text {II }}$ & $S_{I}$ & $\mathrm{~S}_{\text {II }}$ & $\mathrm{S}_{\mathrm{I}}$ & $\mathrm{S}_{\mathrm{II}}$ & $S_{\text {I }}$ & $\mathrm{S}_{\mathrm{II}}$ & $S_{\text {I }}$ & $\mathrm{S}_{\mathrm{II}}$ \\
\hline Irrigation (I) & $* *$ & $* *$ & $* *$ & $* *$ & $* *$ & $* *$ & $* *$ & $* *$ & $* *$ & $* *$ \\
\hline $\mathrm{I}_{120 \%}$ & $70.20 \pm 1.1 \mathrm{a}$ & $70.41 \pm 1.2 \mathrm{a}$ & $65.70 \pm 1.6 a$ & $65.65 \pm 1.5 \mathrm{a}$ & $44.64 \pm 0.63 a$ & $44.60 \pm 0.46 a$ & $0.82 \pm 0.00 \mathrm{a}$ & $0.83 \pm 0.00 \mathrm{a}$ & $5.50 \pm 0.30 \mathrm{a}$ & $5.60 \pm 0.28 a$ \\
\hline $\mathrm{I}_{00 \%}$ & $68.91 \pm 1.7 b$ & $69.22 \pm 1.6 b$ & $68.94 \pm 2.1 \mathrm{a}$ & $67.64 \pm 1.8 \mathrm{a}$ & $42.14 \pm 0.60 \mathrm{~b}$ & $42.80 \pm 0.56 b$ & $0.80 \pm 0.00 \mathrm{~b}$ & $0.81 \pm 0.01 b$ & $4.04 \pm 0.26 b$ & $3.93 \pm 0.23 b$ \\
\hline $\mathrm{I}_{80 \%}$ & $61.65 \pm 1.4 c$ & $62.14 \pm 1.3 c$ & $61.00 \pm 1.6 b$ & $60.50 \pm 1.7 b$ & $36.35 \pm 0.82 c$ & $36.20 \pm 0.72 c$ & $0.78 \pm 0.01 c$ & $0.78 \pm 0.01 c$ & $2.94 \pm 0.35 c$ & $3.04 \pm 0.32 c$ \\
\hline Nitrogen (N) & $* *$ & $* *$ & $* *$ & $* *$ & $* *$ & $* *$ & $* *$ & $* *$ & $* *$ & $* *$ \\
\hline $\mathrm{N}_{165}$ & $65.44 \pm 1.2 b$ & $66.20 \pm 1.1 b$ & $62.52 \pm 1.4 b$ & $63.00 \pm 1.3 b$ & $39.82 \pm 0.69 b$ & $39.64 \pm 0.72 b$ & $0.78 \pm 0.00 \mathrm{~b}$ & $0.79 \pm 0.00 \mathrm{~b}$ & $3.44 \pm 0.27 \mathrm{~b}$ & $3.40 \pm 0.26 b$ \\
\hline $\mathrm{N}_{200}$ & $68.40 \pm 1.1 \mathrm{a}$ & $68.34 \pm 1.0 \mathrm{a}$ & $66.54 \pm 1.4 \mathrm{a}$ & $66.24 \pm 1.6 a$ & $42.34 \pm 0.59 \mathrm{a}$ & $42.92 \pm 0.65 a$ & $0.81 \pm 0.00 \mathrm{a}$ & $0.82 \pm 0.01 \mathrm{a}$ & $4.94 \pm 0.25 a$ & $5.00 \pm 0.30 \mathrm{a}$ \\
\hline $\mathrm{V}_{1}$ & $69.11 \pm 1.0 \mathrm{a}$ & $69.42 \pm 1.1 \mathrm{a}$ & $66.00 \pm 1.9 a$ & $65.14 \pm 1.6 a$ & $42.13 \pm 0.68 a$ & $41.74 \pm 0.74 a$ & $0.81 \pm 0.01 a$ & $0.81 \pm 0.01 \mathrm{a}$ & $4.34 \pm 0.38 \mathrm{a}$ & $4.34 \pm 0.36 a$ \\
\hline $\mathrm{V}_{2}$ & $66.14 \pm 1.2 b$ & $66.73 \pm 1.3 b$ & $65.50 \pm 1.8 \mathrm{a}$ & $65.24 \pm 1.4 a$ & $40.84 \pm 0.88 b$ & $41.07 \pm 0.95 a$ & $0.81 \pm 0.00 \mathrm{a}$ & $0.81 \pm 0.01 \mathrm{a}$ & $4.45 \pm 0.39 \mathrm{a}$ & $4.50 \pm 0.33 a$ \\
\hline $\mathrm{V}_{3}$ & $65.50 \pm 1.4 b$ & $65.64 \pm 1.3 c$ & $62.14 \pm 1.5 b$ & $63.40 \pm 1.3 a$ & $40.20 \pm 0.72 b$ & $41.15 \pm 0.63 a$ & $0.80 \pm 0.00 \mathrm{a}$ & $0.80 \pm 0.01 \mathrm{a}$ & $3.80 \pm 0.27 b$ & $3.81 \pm 0.31 b$ \\
\hline $\mathrm{I} \times \mathrm{N}$ & $* *$ & $* *$ & NS & NS & $* *$ & $* *$ & $* *$ & $* *$ & $* *$ & $* *$ \\
\hline $\mathrm{I} \times \mathrm{V}$ & $* *$ & $* *$ & NS & $*$ & NS & $* *$ & $* *$ & $* *$ & $* *$ & NS \\
\hline $\mathrm{V} \times \mathrm{N}$ & $* *$ & $* *$ & $*$ & NS & $* *$ & $* *$ & NS & NS & NS & $* *$ \\
\hline $\mathrm{I} \times \mathrm{N} \times \mathrm{V}$ & NS & $* *$ & * & $* *$ & NS & NS & NS & $* *$ & $* *$ & $* *$ \\
\hline
\end{tabular}

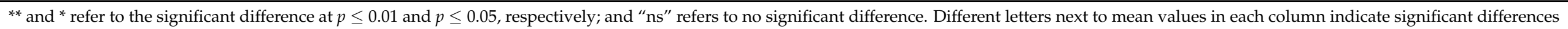
according to the LSD test $(p<0.05)$. 
Table 4. Effect of deficit irrigation, nitrogen fertilizers varieties, and their interaction on growth characteristics of rice plants in $2017\left(\mathrm{~S}_{\mathrm{I}}\right)$ and $2018\left(\mathrm{~S}_{\mathrm{II}}\right)$ seasons.

\begin{tabular}{|c|c|c|c|c|c|c|c|c|}
\hline \multirow{2}{*}{$\begin{array}{l}\text { Source of } \\
\text { Variation }\end{array}$} & \multicolumn{2}{|c|}{$\begin{array}{c}\text { Plant } \\
\text { Height }(\mathrm{cm})\end{array}$} & \multicolumn{2}{|c|}{ Tillers No } & \multicolumn{2}{|c|}{ Effective Tillers No } & \multicolumn{2}{|c|}{ Panicle Length (cm) } \\
\hline & $\mathrm{S}_{\mathrm{I}}$ & $\mathrm{S}_{\mathrm{II}}$ & $\mathrm{S}_{\mathrm{I}}$ & $\mathrm{S}_{\mathrm{II}}$ & $\mathrm{S}_{\mathrm{I}}$ & $\mathrm{S}_{\mathrm{II}}$ & $\mathrm{S}_{\mathrm{I}}$ & $S_{\text {II }}$ \\
\hline Irrigation (I) & $* *$ & $* *$ & $* *$ & * & $*$ & $*$ & $* *$ & $* *$ \\
\hline $\mathrm{I}_{120}$ & $74.73 \pm 0.87 a$ & $75.30 \pm 0.67 a$ & $3.11 \pm 0.08 \mathrm{a}$ & $3.14 \pm 0.09 a$ & $2.95 \pm 0.09 a$ & $2.78 \pm 0.08 \mathrm{a}$ & $20.46 \pm 0.21 \mathrm{a}$ & $20.58 \pm 0.18 a$ \\
\hline $\mathrm{I}_{00}$ & $71.87 \pm 0.65 b$ & $72.26 \pm 0.62 b$ & $2.56 \pm 0.09 b$ & $2.79 \pm 0.08 b$ & $2.45 \pm 0.09 b$ & $2.54 \pm 0.08 b$ & $19.41 \pm 0.24 b$ & $19.38 \pm 0.21 b$ \\
\hline $\mathrm{I}_{80}$ & $67.84 \pm 0.67 c$ & $68.00 \pm 0.63 c$ & $2.44 \pm 0.08 c$ & $2.46 \pm 0.08 c$ & $2.35 \pm 0.09 b$ & $2.17 \pm 0.09 c$ & $18.36 \pm 0.23 c$ & $18.34 \pm 0.20 \mathrm{c}$ \\
\hline Nitrogen (N) & $* *$ & $* *$ & $* *$ & NS & $* *$ & NS & $* *$ & $* *$ \\
\hline $\mathrm{N}_{165}$ & $69.92 \pm 0.67 b$ & $70.01 \pm 0.55 \mathrm{a}$ & $2.54 \pm 0.08 b$ & $2.81 \pm 0.08 \mathrm{a}$ & $2.44 \pm 0.08 b$ & $2.49 \pm 0.09 a$ & $18.87 \pm 0.23 b$ & $18.89 \pm 0.22 b$ \\
\hline $\mathrm{N}_{200}$ & $73.04 \pm 0.70 \mathrm{a}$ & $73.69 \pm 0.59 a$ & $2.85 \pm 0.08 \mathrm{a}$ & $2.80 \pm 0.09 a$ & $2.72 \pm 0.08 \mathrm{a}$ & $2.51 \pm 0.07 a$ & $19.95 \pm 0.19 a$ & $19.97 \pm 0.17 a$ \\
\hline Variety (V) & $* *$ & $* *$ & NS & NS & NS & * & $* *$ & $* *$ \\
\hline $\mathrm{V}_{1}$ & $75.79 \pm 0.77 a$ & $76.49 \pm 0.73 a$ & $2.86 \pm 0.09 a$ & $3.01 \pm 0.09 a$ & $2.70 \pm 0.08 \mathrm{a}$ & $2.80 \pm 0.06 a$ & $20.57 \pm 0.21 a$ & $20.56 \pm 0.19 a$ \\
\hline $\mathrm{V}_{2}$ & $67.31 \pm 0.57 c$ & $67.47 \pm 0.65 b$ & $2.65 \pm 0.09 b$ & $2.76 \pm 0.09 b$ & $2.59 \pm 0.10 b$ & $2.44 \pm 0.06 b$ & $18.54 \pm 0.23 c$ & $18.57 \pm 0.24 \mathrm{c}$ \\
\hline $\mathrm{V}_{3}$ & $71.34 \pm 0.57 b$ & $71.59 \pm 0.59 b$ & $2.59 \pm 0.10 b$ & $2.64 \pm 0.09 b$ & $2.44 \pm 0.09 c$ & $2.26 \pm 0.07 \mathrm{~b}$ & $19.11 \pm 0.20 b$ & $19.14 \pm 0.22 b$ \\
\hline $\mathrm{I} \times \mathrm{N}$ & $* *$ & $* *$ & $* *$ & $* *$ & $*$ & $*$ & $* *$ & $* *$ \\
\hline $\mathrm{I} \times \mathrm{V}$ & $* *$ & $* *$ & $* *$ & * & $* *$ & $* *$ & $* *$ & $* *$ \\
\hline $\mathrm{V} \times \mathrm{N}$ & $* *$ & $* *$ & NS & * & $*$ & * & $* *$ & $* *$ \\
\hline $\mathrm{I} \times \mathrm{N} \times \mathrm{V}$ & NS & NS & $*$ & $*$ & NS & NS & $*$ & $*$ \\
\hline
\end{tabular}

** and * refer to the significant difference at $p \leq 0.01$ and $p \leq 0.05$, respectively; and "ns" refers to no significant difference. Different letters next to mean values in each column indicate significant differences according to the LSD test $(p<0.05)$.

\subsection{Yield Components}

Yield components of, i.e., panicle length $(\mathrm{cm})$, grains number per panicle, panicle weight, weight of grain per panicle $(\mathrm{g})$ and weight of 100 grain $(\mathrm{g})$, were significantly affected by irrigation and nitrogen nutrition treatments. Results in Table 5 showed that rice variety Giza 178 yielded the highest values of these traits under irrigation and nutrition level $\left(\mathrm{I}_{120} \times \mathrm{N}_{2}\right)$, while the lowest values were yielded by Giza 177 under $\left(\mathrm{I}_{80} \times \mathrm{N}_{1}\right)$. Among irrigation regimes $\left(\mathrm{I}_{120}\right)$ produced the highest averages of these traits, that gradually reduced by increasing drought level. The reduction percent amounted to $5.48,7.78,13.63$, 18.41 and $11.07 \%$ respectively, as compared with those obtained at moderate stress level $\left(\mathrm{I}_{100}\right)$ and by $10.57,17.83,29.6632 .61$ and $18.38 \%$ respectively compared to $\left(\mathrm{I}_{80}\right)$. The obtained results were in line with those reported by [52] who found that yield components of rice crop (panicle number, panicle length, 100-grain weight and grain yield) decreased with increasing water stress especially if it occurred at the stage of panicle initiation. Ref. $[17,62]$ noted that depending upon the stress severity the plant physiological responses, the apical development rate, biomass production, panicle development, spikelet number, and grain yield were decreased.

However, applying nitrogen fertilization at $\mathrm{N}_{2}$ resulted in an increase in panicle length $(\mathrm{cm})$, grains number per panicle, panicle weight, weight of grain per panicle $(\mathrm{g})$ and weight of 100 grain (g) by $5.72,10.81,12.85,11.91$ and $5.21 \%$ as compared to $\mathrm{N}_{1}$. Inter varietal comparison showed that, yield component traits were significantly differed in both seasons. Results are in agreement with those revealed by $[63,64]$ who noted that the application of $\mathrm{N}$ fertilizers significantly increased the yield and yield components of rice.

\subsection{Grain, Straw and Biological Yield}

Results presented in Table 6 show that, grain, straw, biological yield and grains $\mathrm{N}$ content were varied significantly among the grown rice varieties as affected by both irrigation and nitrogen nitration management. As average (2017-2018) rice variety Giza 178 gave the highest grain, straw and biological yield 7.97, 12.23 and $20.19 \mathrm{t} \mathrm{ha}^{-1}$ respectively, while Giza $_{177}$ recorded the lowest yields $\left(5.78,8.84\right.$ and $14.61 \mathrm{t} \mathrm{ha}^{-1}$ respectively). As presented above in (Tables 3-5) the higher application of irrigation water $\left(\mathrm{I}_{120}\right)$ improved the plant water statues, enhanced growth and development of rice plants that contributed to achieve the maximum values for grain yield $\left(8.11 \mathrm{t} \mathrm{ha}^{-1}\right)$, straw yield $\left(11.89 \mathrm{t} \mathrm{ha}^{-1}\right)$ and biological yield $\left(20.00 \mathrm{t} \mathrm{ha}^{-1}\right)$. Furthermore, comparing with irrigation treatment $\left(\mathrm{I}_{120}\right)$, 
moderate irrigation regime $\left(\mathrm{I}_{100}\right)$ reduced the grain, straw and biological yield of grown lowland rice varieties. The reductions were by $10.98,5.55$ and $7.75 \%$, respectively, and by $34.18,26.53$ and $29.63 \%$, respectively, under the application of deficit irrigation treatment $\left(\mathrm{I}_{80}\right)$. A similar trend was observed by $[62,65-67]$.

Table 5. Effect of deficit irrigation, nitrogen fertilizer varieties, and their interaction on yield component of rice in $2017\left(\mathrm{~S}_{\mathrm{I}}\right)$ and $2018\left(\mathrm{~S}_{\text {II }}\right)$ seasons.

\begin{tabular}{|c|c|c|c|c|c|c|c|c|}
\hline \multirow{2}{*}{$\begin{array}{l}\text { Source of } \\
\text { Variation }\end{array}$} & \multicolumn{2}{|c|}{ Grains No/Panicle } & \multicolumn{2}{|c|}{ Panicle Weight } & \multicolumn{2}{|c|}{ Weight of Grains/Panicle } & \multicolumn{2}{|c|}{$\mathrm{W}$ of $100 \mathrm{~g}$} \\
\hline & $\mathrm{S}_{\mathrm{I}}$ & $\mathrm{S}_{\mathrm{II}}$ & $\mathrm{S}_{\mathrm{I}}$ & $\mathrm{S}_{\mathrm{II}}$ & $\mathrm{S}_{\mathrm{I}}$ & $\mathrm{S}_{\mathrm{II}}$ & $\mathrm{S}_{\mathrm{I}}$ & $\mathrm{S}_{\mathrm{II}}$ \\
\hline $\begin{array}{l}\text { Irrigation } \\
\text { (I) }\end{array}$ & $* *$ & $* *$ & $* *$ & $* *$ & ** & $* *$ & $* *$ & $* *$ \\
\hline $\mathrm{I}_{120}$ & $93.56 \pm 1.7 \mathrm{a}$ & $94.45 \pm 1.6 \mathrm{a}$ & $2.50 \pm 0.03 a$ & $2.49 \pm 0.09 a$ & $2.24 \pm 0.03 a$ & $2.27 \pm 0.13 a$ & $2.39 \pm 0.29 a$ & $2.40 \pm 0.28 \mathrm{a}$ \\
\hline $\mathrm{I}_{00}$ & $86.34 \pm 1.9 b$ & $87.05 \pm 1.8 b$ & $2.15 \pm 0.06 b$ & $2.16 \pm 0.10 b$ & $1.80 \pm 0.06 b$ & $1.88 \pm 0.16 b$ & $2.10 \pm 0.47 \mathrm{~b}$ & $2.16 \pm 0.36 b$ \\
\hline $\mathrm{I}_{80}$ & $77.16 \pm 1.5 c$ & $78.18 \pm 1.6 c$ & $1.75 \pm 0.07 \mathrm{c}$ & $1.76 \pm 0.06 c$ & $1.46 \pm 0.06 c$ & $1.58 \pm 0.09 c$ & $1.89 \pm 0.49 c$ & $2.02 \pm 0.45 c$ \\
\hline $\begin{array}{l}\text { Nitrogen } \\
(\mathrm{N})\end{array}$ & $* *$ & $* *$ & $* *$ & $* *$ & $* *$ & $* *$ & $* *$ & $* *$ \\
\hline $\mathrm{N}_{165}$ & $82.99 \pm 1.6 b$ & $83.63 \pm 1.5 b$ & $1.98 \pm 0.06 b$ & $2.00 \pm 0.06 b$ & $1.72 \pm 0.06 b$ & $1.81 \pm 0.10 \mathrm{~b}$ & $2.07 \pm 0.45 b$ & $2.16 \pm 0.39 b$ \\
\hline $\mathrm{N}_{200}$ & $88.39 \pm 1.6 a$ & $89.47 \pm 1.7 a$ & $2.27 \pm 0.06 a$ & $2.27 \pm 0.12 \mathrm{a}$ & $1.93 \pm 0.06 a$ & $2.02 \pm 0.16 a$ & $2.19 \pm 0.49 a$ & $2.26 \pm 0.38 a$ \\
\hline Variety $(\mathrm{V})$ & $* *$ & $* *$ & $* *$ & $* *$ & $* *$ & ** & ** & ** \\
\hline $\mathrm{V}_{1}$ & $97.20 \pm 1.6 \mathrm{a}$ & $95.85 \pm 1.8 \mathrm{a}$ & $2.46 \pm 0.04 \mathrm{a}$ & $2.48 \pm 0.11 \mathrm{a}$ & $2.20 \pm 0.04 \mathrm{a}$ & $2.25 \pm 0.08 \mathrm{a}$ & $2.27 \pm 0.26 \mathrm{a}$ & $2.34 \pm 0.36 a$ \\
\hline $\mathrm{V}_{2}$ & $77.00 \pm 1.2 \mathrm{c}$ & $79.01 \pm 1.3 c$ & $1.81 \pm 0.07 \mathrm{c}$ & $1.80 \pm 0.09 c$ & $1.41 \pm 0.07 \mathrm{c}$ & $1.54 \pm 0.11 c$ & $1.84 \pm 0.65 c$ & $1.95 \pm 0.54 c$ \\
\hline $\mathrm{V}_{3}$ & $82.87 \pm 1.3 b$ & $84.80 \pm 1.3 b$ & $2.11 \pm 0.07 \mathrm{~b}$ & $2.13 \pm 0.08 b$ & $1.88 \pm 0.12 b$ & $1.94 \pm 0.09 b$ & $2.27 \pm 0.67 \mathrm{~b}$ & $2.29 \pm 0.57 b$ \\
\hline $\mathrm{I} \times \mathrm{N}$ & $* *$ & $* *$ & $* *$ & * & * & $* *$ & NS & $* *$ \\
\hline $\mathrm{I} \times \mathrm{V}$ & $* *$ & $* *$ & $* *$ & $* *$ & $* *$ & $* *$ & $* *$ & $* *$ \\
\hline $\mathrm{V} \times \mathrm{N}$ & $* *$ & $* *$ & NS & $* *$ & $* *$ & * & NS & $* *$ \\
\hline $\mathrm{I} \times \mathrm{N} \times \mathrm{V}$ & NS & NS & $* *$ & $* *$ & * & $* *$ & $*$ & $* *$ \\
\hline
\end{tabular}

${ }^{* *}$ and * refer to the significant difference at $p \leq 0.01$ and $p \leq 0.05$, respectively; and "ns" refers to no significant difference. Different letters next to mean values in each column indicate significant differences according to the LSD test $(p<0.05)$.

However, nitrogen application gave an appositive effect and improved the productivity of all grown rice varieties. Data in Table 6 showed that increasing the nitrogen fertilization dose from $\mathrm{N}_{1}$ to $\mathrm{N}_{2}$ resulted in an increase in grain, straw and biological yield by $12.66,18.20$ and $15.99 \%$, respectively. Nitrogen application could produce promoted root growth, enhanced water and nitrogen extraction from soil, resulting in better crop growth and higher yield productivity. Similar trend was noted by [68] who observed an increase in grain yield with the increasing of nitrogen application levels. The combined effect of $(\mathrm{I} \times \mathrm{N})$ on grain and straw was found to be significant during both seasons except their effect on straw yield in the second year was non-significant. The effect of $(\mathrm{V} \times \mathrm{N})$ during two seasons was non-significant. Meanwhile, the effect of $(\mathrm{I} \times \mathrm{V} \times \mathrm{N})$ was significant.

\subsection{Irrigation Water Applied and Water Productivity}

Results in Table 7 show that total water applied was varied between the applied irrigation treatments. The lowest amount of irrigation water $\left(646 \mathrm{~mm} \mathrm{ha}^{-1}\right)$ required was at $\left(\mathrm{I}_{80}\right)$, while the highest $\left(970 \mathrm{~mm} \mathrm{ha}^{-1}\right)$ was needed for $\left(\mathrm{I}_{120}\right)$. According to the grain yield obtained under each watering treatment, the applied irrigation water and crop water consumption, irrigation water productivity (IWP) and crop water productivity (CWP) were significantly differed $(p \leq 0.05)$ in both growing seasons. Among irrigation treatments watering at $\left(\mathrm{I}_{100}\right)$ gave the highest values of IWP and CWP by 0.89 and $1.28\left(\mathrm{~kg} \mathrm{~m}^{3}\right)$, respectively, when comparing with other irrigation treatments. In addition, increasing nitrogen application dose up to $\mathrm{N}_{2}$ resulted in higher IWP and CWP by 12.50 and $12.17 \%$, respectively, than $\mathrm{N}_{1}$ (as average for both seasons). Between rice varieties, Giza 179 corresponding to its high grain productivity which resulted in the highest value as averages of IWP $\left(0.99 \mathrm{Kg} \mathrm{m}^{-3}\right)$ and CWP $\left(1.41 \mathrm{~kg} \mathrm{~m}^{-3}\right)$ meanwhile, the lowest IWP and CWP amounted 0.71 and $1.02 \mathrm{~kg} \mathrm{~m}^{-3}$, respectively, noted for Giza 177 .

Table 6. Effect of deficit irrigation, nitrogen fertilizers varieties, and their interaction on grain yield, straw yield, biological yield, and grains $\mathrm{N}$ content of rice plants in $2017\left(\mathrm{~S}_{\mathrm{I}}\right)$ and $2018\left(\mathrm{~S}_{\mathrm{II}}\right)$ seasons.

\begin{tabular}{|c|c|c|c|c|}
\hline Source of & $\begin{array}{l}\text { Grain Yield } \\
\left(t \mathrm{ha}^{-1}\right)\end{array}$ & $\begin{array}{l}\text { Straw Yield } \\
\left(\mathrm{t} \mathrm{ha} \mathbf{a}^{-1}\right)\end{array}$ & $\begin{array}{l}\text { Biological Yield } \\
\quad\left(\mathrm{t} \mathrm{ha}^{-1}\right)\end{array}$ & $\begin{array}{c}\mathrm{N} \\
(\%)\end{array}$ \\
\hline & $S_{\text {II }}$ & $S_{\text {II }}$ & $S_{\text {II }}$ & $\mathrm{S}_{\mathrm{II}}$ \\
\hline
\end{tabular}


Table 7. Effect of deficit irrigation, nitrogen fertilizer varieties, and their interaction on grain yield, straw yield, biological yield, irrigation water productivity and crop water productivity of rice plants in $2017\left(\mathrm{~S}_{\mathrm{I}}\right)$ and 2018 ( $\left.\mathrm{S}_{\mathrm{II}}\right)$ seasons.

\begin{tabular}{|c|c|c|c|c|c|c|}
\hline \multirow{2}{*}{$\begin{array}{l}\text { Source of } \\
\text { Variation }\end{array}$} & \multicolumn{2}{|c|}{$\begin{array}{l}\text { Irrigation Water Applied } \\
\qquad\left(\mathrm{m}^{3} \mathrm{ha}^{-1}\right)\end{array}$} & \multicolumn{2}{|c|}{$\begin{array}{l}\text { Irrigation Water Productivity } \\
\qquad\left(\mathrm{kg} \mathrm{m}^{-3}\right)\end{array}$} & \multicolumn{2}{|c|}{$\begin{array}{c}\text { Crop Water Productivity } \\
\left(\mathrm{kg} \mathrm{m}^{-3}\right)\end{array}$} \\
\hline & $S_{I}$ & $S_{\text {II }}$ & $\mathrm{S}_{\mathrm{I}}$ & $\mathrm{S}_{\mathrm{II}}$ & $\mathrm{S}_{\mathrm{I}}$ & $\mathrm{S}_{\mathrm{II}}$ \\
\hline Irrigation (I) & & & $* *$ & $* *$ & $* *$ & $* *$ \\
\hline $\mathrm{I}_{120} \%$ & 9661 & 9733 & $0.83 \pm 0.01 b$ & $0.84 \pm 0.01 b$ & $1.19 \pm 0.09 b$ & $1.20 \pm 0.12 b$ \\
\hline $\mathrm{I}_{00 \%}$ & 8051 & 8111 & $0.89 \pm 0.02 \mathrm{a}$ & $0.90 \pm 0.02 \mathrm{a}$ & $1.27 \pm 0.08 \mathrm{a}$ & $1.29 \pm 0.09 a$ \\
\hline $\mathrm{I}_{80 \%} \%$ & 6441 & 6489 & $0.82 \pm 0.01 b$ & $0.83 \pm 0.01 b$ & $1.17 \pm 0.11 c$ & $1.19 \pm 0.08 b$ \\
\hline Nitrogen $(\mathrm{N})$ & & & $* *$ & $* *$ & $* *$ & $* *$ \\
\hline $\mathrm{N}_{165}$ & 8051 & 8111 & $0.79 \pm 0.01 b$ & $0.81 \pm 0.01 b$ & $1.13 \pm 0.09 c$ & $1.16 \pm 0.08 c$ \\
\hline $\mathrm{N}_{200}$ & 8051 & 8111 & $0.90 \pm 0.02 a$ & $0.90 \pm 0.02 a$ & $1.29 \pm 0.06 a$ & $1.29 \pm 0.07 a$ \\
\hline Variety (V) & & & ** & ** & ** & ** \\
\hline V1 & 8051 & 8111 & $0.98 \pm 0.02 \mathrm{a}$ & $0.99 \pm 0.02 \mathrm{a}$ & $1.40 \pm 0.11 \mathrm{a}$ & $1.42 \pm 0.09 a$ \\
\hline $\mathrm{V} 2$ & 8051 & 8111 & $0.72 \pm 0.00 c$ & $0.71 \pm 0.01 c$ & $1.03 \pm 0.09 c$ & $1.02 \pm 0.0 c$ \\
\hline V3 & 8051 & 8111 & $0.84 \pm 0.01 b$ & $0.87 \pm 0.02 b$ & $1.20 \pm 0.08 b$ & $1.24 \pm 0.10 \mathrm{~b}$ \\
\hline $\mathrm{I} \times \mathrm{N}$ & & & ** & ** & ** & ** \\
\hline $\mathrm{I} \times \mathrm{V}$ & & & $* *$ & $* *$ & $* *$ & $* *$ \\
\hline $\mathrm{V} \times \mathrm{N}$ & & & NS & NS & * & $* *$ \\
\hline $\mathrm{I} \times \mathrm{N} \times \mathrm{V}$ & & & NS & NS & NS & NS \\
\hline
\end{tabular}

** and * refer to the significant difference at $p \leq 0.01$ and $p \leq 0.05$, respectively; and "ns" refers to no significant difference. Different letters next to mean values in each column indicate significant difference according to the LSD test $(p<0.05)$.

Many studies have been summarized that rice cultivation under flooded condition consumes approximately 20,000 $\mathrm{m}^{3} \mathrm{ha}^{-1}$ [7]. In North Delta, Egypt [69] estimated water requirements for flooded-rice by $19,000 \mathrm{~m}^{3} \mathrm{ha}^{-1}$ and water utilization efficiency by $48 \%$. Similar results reported by [70] who found that rice normally needs under traditional methods in Egypt a water application of about $20,000 \mathrm{~m}^{3} \mathrm{ha}^{-1}$. Studies conducted by [11] concluded that the water requirement of paddy fields in Egypt is about $1800-2200 \mathrm{~mm} \mathrm{ha}^{-1}$. Therefore, compared with previous studies, the current investigation aimed to create new environmental cultivation conditions to grow lowland rice varieties (aerobically) in nonpuddled fields under non-flooded conditions and maintain a profitable grain yield could save irrigation water by $60 \%$. Moreover, results concluded that lowland rice variety Giza 178 was observed to be more tolerant than other varieties, Giza 177 and Sakha104, while v. Giza $_{177}$ was much affected by deficiency of irrigation water. A similar trend was reported by [3].

\subsection{Correlation Analysis}

Results in Tables 8 and 9 illustrated the correlation coefficients between rice grain yield and the other yield components. This type of examination could be used as an appropriate instrument to indicate which one of them is positive and greatly associated with the obtained yield of grains.

Table 8. A matrix of simple correlation coefficients between grain yield and other important traits estimated for 2017 and 2018 seasons.

\begin{tabular}{|c|c|c|c|c|c|c|c|c|c|c|c|c|}
\hline & Parameter & Season & 1 & 2 & 3 & 4 & 5 & 6 & 7 & 8 & 9 & 10 \\
\hline \multirow{2}{*}{1} & Grain & 2017 & 1 & & & & & & & & & \\
\hline & yield & 2018 & 1 & & & & & & & & & \\
\hline \multirow{2}{*}{2} & Plant & 2017 & $0.920 * *$ & 1 & & & & & & & & \\
\hline & height & 2018 & $0.921 * *$ & 1 & & & & & & & & \\
\hline \multirow{2}{*}{3} & & 2017 & $0.486^{* *}$ & $0.469 * *$ & 1 & & & & & & & \\
\hline & Branch No & 2018 & $0.361^{* *}$ & $0.308^{* *}$ & 1 & & & & & & & \\
\hline \multirow{2}{*}{4} & No snike & 2017 & $0.405^{* *}$ & $0.396^{* *}$ & $0.712^{* *}$ & 1 & & & & & & \\
\hline & No spike & 2018 & $0.377^{* *}$ & $0.313 * *$ & $0.568^{* *}$ & 1 & & & & & & \\
\hline \multirow{2}{*}{5} & Spike & 2017 & $0.827^{* *}$ & $0.815^{* *}$ & $0.535^{* *}$ & $0.455^{* *}$ & 1 & & & & & \\
\hline & length & 2018 & $0.819 * *$ & $0.775 * *$ & $0.306^{* *}$ & $0.349^{* *}$ & 1 & & & & & \\
\hline \multirow[b]{2}{*}{6} & & 2017 & $0.903^{* *}$ & $0.879 * *$ & $0.430^{* *}$ & $0.380^{* *}$ & $0.844^{* *}$ & 1 & & & & \\
\hline & Grain No & 2018 & $0.894^{* *}$ & $0.849 * *$ & $0.268^{*}$ & $0.294^{* *}$ & $0.736^{* *}$ & 1 & & & & \\
\hline 7 & Spike & 2017 & $0.915^{* *}$ & $0.866^{* *}$ & $0.541^{* *}$ & $0.454^{* *}$ & $0.841^{* *}$ & $0.872 * *$ & 1 & & & \\
\hline
\end{tabular}


Table 9. Correlation coefficient $(r)$, coefficient of determination $\left(R^{2}\right)$ and standard error of the estimates (SEE) for predicting grain yield for $S_{I}(2017)$ and $S_{\text {II }}(2018)$ seasons.

\begin{tabular}{cccccl}
\hline Season & $\boldsymbol{r}$ & $\boldsymbol{R}^{2}$ & SEE & Significance & \multicolumn{1}{c}{ Fitted Equation } \\
\hline 2017 & 0.961 & 0.924 & 0.33 & $* * *$ & $\begin{array}{l}\text { Grain yield }=-4.1+0.09 \text { plant height }+1.69 \text { spike weight }+0.179 \\
\text { skillets no }-0.074 \text { weight of } 1000 \text { grain } \\
\text { Grain yield }=-6.18+0.08 \text { plant height }+0.72 \text { spike weight }+0.031 \\
\text { grain no }+0.104 \text { spike length }\end{array}$ \\
\hline
\end{tabular}

*** indicate correlation is significant at the 0.01 level.

It was observed that grain yield was positive and strongly correlated with plant height, spike length, grain no/spike then followed by spike weight, which validates their economic importance.

Data in Table 9 show that plant height and spike weight in both seasons were significantly $(p \leq 0.01)$ contributed to variations in rice grain yield.

\section{Conclusions}

Cultivating rice aerobically under deficit irrigation has been observed to be used as an effective and efficient approach in saving irrigation water and improving IWP compared with the flooding system. Additionally, improving nitrogen supply enhanced rice crop productivity under deficit irrigation conditions. The combined effect of $\left(\mathrm{I}_{120} \times \mathrm{N}_{2}\right)$ treatment achieved the greatest values of all agronomic and physiological traits, grain and straw yield of rice. Applying of irrigation water at $\left(\mathrm{I}_{2}\right)$ produced the maximum (IWP) and (CWP) by 0.89 and $1.28 \mathrm{~kg} \mathrm{~m}^{-3}$, respectively, compared with other irrigation schedules. Rice variety $\left(\mathrm{Giza}_{178}, \mathrm{V1}\right)$, gave the highest CWP and grain yield which amounted to 1.41 and 7.97, respectively. Consequently, it could be a suitable genotype for improving rice productivity under drought conditions as compared with other tested rice varieties. Thus, based on the results of the current study the incorporating deficit irrigation technique at level (100 of ETc) with nitrogen application at $120 \%$ of recommended dose could be a valuable agro-management strategy for maintaining relatively high yields of some sensitivedrought Egyptian rice varieties and saving irrigation water supply by $50-60 \%$ compared to the conventional rice cultivation method.

Author Contributions: Conceptualization, N.M.A., M.O.A.R. and T.A.A.E.-M.; methodology, N.M.A., M.O.A.R., W.M.S. and T.A.A.E.-M.; formal analysis, T.A.A.E.-M., M.O.A.R., N.M.A. and W.M.S.; investigation, T.A.A.E.-M., W.M.S., N.M.A. and M.O.A.R.; resources N.M.A., T.A.A.E.-M., W.M.S., S.A.A.E.-M., M.A.A.-R., E.F.A., A.M. and M.O.A.R.; data curation, N.M.A., M.O.A.R., T.A.A.E.-M.; E.F.A., A.M. and M.A.A.-R.; writing—original draft preparation, N.M.A., M.O.A.R. and T.A.A.E.-M.; and S.A.A.E.-M.; writing-review and editing, N.M.A., T.A.A.E.-M., W.M.S., A.A.A.L.; visualization, N.M.A., M.O.A.R., T.A.A.E.-M.; W.M.S., E.F.A., A.M., S.A.A.E.-M. and M.A.A.-R.; supervision, N.M.A., T.A.A.E.-M. and M.O.A.R. project administration, N.M.A., M.O.A.R. and T.A.A.E.-M.; All authors have read and agreed to the published version of the manuscript.

Funding: This research received no external funding.

Institutional Review Board Statement: Not applicable.

Informed Consent Statement: Not applicable.

Data Availability Statement: The data presented in this study are available upon request from the corresponding author.

Acknowledgments: The authors are thankful to Taif University Researchers Supporting Project number (TURSP-2020/110), Taif University, Saudi Arabia, for the financial support and research facilities.

Conflicts of Interest: The authors declare no conflict of interest. 


\section{References}

1. Manjappa, G.U.; Shailaja, H. Identification of drought tolerant and high yielding genotypes of rice under aerobic condition. Oryza 2014, 51, 273-278.

2. FAOSTAT. Food and Agriculture Data; Food and Agriculture Organization: Rome, Italy, 2019.

3. Tantawi, A.; Ghanem, S.A. Water use efficiency in rice culture. In Future of Water Management for Rice in Mediterranean Climate Areas: Proceedings of the Workshops; CIHEAM: Montpellier, France, 1999; pp. 39-45.

4. Bouman, B.A.M. Water Management in Irrigated Rice: Coping with Water Scarcity; Internationa Rice Research Institute: Los Baños, Philippines, 2007.

5. $\quad$ Brown, K.W.; Turner, F.T.; Thomas, J.C.; Deuel, L.E.; Keener, M.E. Water balance of flooded rice paddies. Agric. Water Manag. 1977, 1, 277-291. [CrossRef]

6. McCauley, G.N. Sprinkler vs. flood irrigation in traditional rice production regions of southeast Texas. Agron. J. 1990, 82, 677-683. [CrossRef]

7. Tuong, T.P.; Bam, B.; Mortimer, M. More Rice, Less Water-Integrated Approaches for Increasing Water Productivity in Irrigated Rice-Based Systems in Asia. Plant Prod. Sci. 2005, 3, 231-241. [CrossRef]

8. WWAP, U. World Water Assessment Programme: The United Nations World Water Development Report 4: Managing Water under Uncertainty and Risk; UNESCO: Paris, France, 2012.

9. Saxena, R.; Vanga, S.K.; Wang, J.; Orsat, V.; Raghavan, V. Millets for food security in the context of climate change: A review. Sustainability 2018, 10, 2228. [CrossRef]

10. Abd El-Mageed, T.A.; Rady, M.O.A.; Semida, W.M.; Shaaban, A.; Mekdad, A.A.A. Exogenous Micronutrients Modulate Morphophysiological Attributes, Yield, and Sugar Quality in Two Salt-Stressed Sugar Beet Cultivars. J. Soil Sci. Plant Nutr. 2021, 1-16. [CrossRef]

11. Watanabe, T. Irrigation water requirement. In The Japanese Society of Irrigation, Drainage and Reclamation Engineering (JSIDRE), Editor; Advanced Paddy Field Engineering; Shinzansha Sci. \& Tech.: Tokyo, Japan, 1995; pp. 31-50.

12. English, M.J.; Nuss, G.S. Designing for deficit irrigation. J. Irrig. Drain. Div. 1982, 108, 91-106. [CrossRef]

13. Abd El-Mageed, T.A.; El-Sherif, A.M.A.; Ali, M.M.; Abd El-Wahed, M.H. Combined effect of deficit irrigation and potassium fertilizer on physiological response, plant water status and yield of soybean in calcareous soil. Arch. Agron. Soil Sci. 2017, 63, 827-840. [CrossRef]

14. Rady, M.O.A.; Semida, W.M.; Howladar, S.M.; Abd El-Mageed, T.A. Raised beds modulate physiological responses, yield and water use efficiency of wheat (Triticum aestivum L.) under deficit irrigation. Agric. Water Manag. 2021, 245, 106629. [CrossRef]

15. Moustafa, E.S.A.; El-Sobky, E.-S.E.A.; Farag, H.I.A.; Yasin, M.A.T.; Attia, A.; Rady, M.O.A.; Awad, M.F.; Mansour, E. Sowing Date and Genotype Influence on Yield and Quality of Dual-Purpose Barley in a Salt-Affected Arid Region. Agronomy 2021 11, 717. [CrossRef]

16. Abd El-Mageed, T.A.; Semida, W.M.; Rady, M.M. Moringa leaf extract as biostimulant improves water use efficiency, physiobiochemical attributes of squash plants under deficit irrigation. Agric. Water Manag. 2017, 193, 46-54. [CrossRef]

17. Yang, X.; Wang, B.; Chen, L.; Li, P.; Cao, C. The different influences of drought stress at the flowering stage on rice physiological traits, grain yield, and quality. Sci. Rep. 2019, 9, 1-12. [CrossRef]

18. Palanog, A.D.; Swamy, B.M.; Shamsudin, N.A.A.; Dixit, S.; Hernandez, J.E.; Boromeo, T.H.; Kumar, A. Grain yield QTLs with consistent-effect under reproductive-stage drought stress in rice. F. Crop. Res. 2014, 161, 46-54. [CrossRef]

19. Saud, S.; Fahad, S.; Yajun, C.; Ihsan, M.Z.; Hammad, H.M.; Nasim, W.; Alharby, H. Effects of nitrogen supply on water stress and recovery mechanisms in Kentucky bluegrass plants. Front. Plant Sci. 2017, 8, 983. [CrossRef] [PubMed]

20. Noor, M.A. Nitrogen management and regulation for optimum NUE in maize-A mini review. Cogent Food Agric. 2017, 3, 1348214. [CrossRef]

21. Ghoneim, A.M.; Gewaily, E.E.; Osman, M.M. Effects of nitrogen levels on growth, yield and nitrogen use efficiency of some newly released Egyptian rice genotypes. Open Agric. 2018, 3, 310-318. [CrossRef]

22. Yoshida, S. Physiological aspects of grain yield. Annu. Rev. Plant Physiol. 1972, 23, 437-464. [CrossRef]

23. Ebaid, R.A.; Ghanem, S.A. Productivity of Giza 177 rice variety grown after different winter crops and fertilized with different nitrogen levels. Egypt. J. Agric. Res. 2000, 78, 717-731.

24. El-Batal, M.A.; Abdel-Gawad, M.H.; Abdou, F.A.; Abdel-Aziz, E.A. Uniconazole application as antilodging for rice plants fertilized with high nitrogen rate. Zagazig J. Agric. Res. 2004, 31, 473-490.

25. Filgueiras, L.; Silva, R.; Almeida, I.; Vidal, M.; Baldani, J.I.; Meneses, C.H.S.G. Gluconacetobacter diazotrophicus mitigates drought stress in Oryza sativa L. Plant Soil 2020, 451, 57-73. [CrossRef]

26. Yoseftabar, S. Effect nitrogen management on panicle structure and yield in rice (Oryza sativa L.). Int. J. Agric. Crop Sci. 2013, 5, 1224-1227.

27. Otoo, E.; Ishii, R.; Kumura, A. Interaction of nitrogen supply and soil water stress on photosynthesis and transpiration in rice. Jpn. J. Crop Sci. 1989, 58, 424-429. [CrossRef]

28. Castillo, E.G.; Buresh, R.J.; Ingram, K.T. Lowland rice yield as affected by timing of water deficit and nitrogen fertilization. Agron. J. 1992, 84, 152-159. [CrossRef]

29. Shangguan, Z.P.; Shao, M.A.; Dyckmans, J. Nitrogen nutrition and water stress effects on leaf photosynthetic gas exchange and water use efficiency in winter wheat. Environ. Exp. Bot. 2000, 44, 141-149. [CrossRef] 
30. Ding, L.; Lu, Z.; Gao, L.; Guo, S.; Shen, Q. Is nitrogen a key determinant of water transport and photosynthesis in higher plants upon drought stress? Front. Plant Sci. 2018, 9, 1143. [CrossRef] [PubMed]

31. Guo, S.; Chen, G.; Zhou, Y.; Shen, Q. Ammonium nutrition increases photosynthesis rate under water stress at early development stage of rice (Oryza sativa L.). Plant Soil 2007, 296, 115-124. [CrossRef]

32. Shatil-Cohen, A.; Attia, Z.; Moshelion, M. Bundle-sheath cell regulation of xylem-mesophyll water transport via aquaporins under drought stress: A target of xylem-borne ABA? Plant J. 2011, 6, 72-80. [CrossRef] [PubMed]

33. Ren, B.; Wang, M.; Chen, Y.; Sun, G.; Li, Y.; Shen, Q.; Guo, S. Water absorption is affected by the nitrogen supply to rice plants. Plant Soil 2015, 396, 397-410. [CrossRef]

34. Agami, R.A.; Alamri, S.A.M.; Abd El-Mageed, T.A.; Abousekken, M.S.M.; Hashem, M. Role of exogenous nitrogen supply in alleviating the deficit irrigation stress in wheat plants. Agric. Water Manag. 2018, 210, 261-270. [CrossRef]

35. Klute, A.; Dirksen, C. Hydraulic conductivity and diffusivity. Laboratory methods. Methods Soil Anal. Part 1. Phys. Mineral. Methods 1986, 9, 687-734.

36. Page, A.I.; Miller, R.H.; Keeny, D.R. Methods of Soil Analysis. In Part II. Chemical and Microbiological Methods, 2nd ed.; American Society of Agronomy: Madison, WI, USA, 1982; pp. 225-246.

37. Gaballah, M.M.; Metwally, A.M.; Skalicky, M.; Hassan, M.M.; Brestic, M.; El Sabagh, A.; Fayed, A.M. Genetic Diversity of Selected Rice Genotypes under Water Stress Conditions. Plants 2021, 10, 27. [CrossRef]

38. Sariam, O.; Azmi, M.; Chan, C.S.; Badrulhadza, A.; Mohd Khusairy, K.; Mohd Fitri, M.; Alicia, J.A.; Rosnani, H.; Shamsul, S.A. Aerobic Rice Manual; MARDI Press: Kuala Lumpur, Malaysia, 2015.

39. Allen, R.G.; Pereira, L.S.; Raes, D.; Smith, M. Crop evapotranspiration: Guidelines for computing crop requirements. Irrig. Drain. Pap. No. 56 FAO 1998, 300, D05109.

40. Israelsen, O.W.; Hansen, V.C. Irrigation Principles and Practices; John Wiley \& Sons Inc.: New York, NY, USA, 1962.

41. Maxwell, K.; Johnson, G.N. Chlorophyll fluorescence-A practical guide. J. Exp. Bot. 2000, 51, 659-668. [CrossRef]

42. Spoustová, P.; Synková, H.; Valcke, R.; Čevrovská, N. Chlorophyll a fluorescence as a tool for a study of the Potato virus Y effects on photosynthesis of nontransgenic and transgenic Pssu-ipt tobacco. Photosynthetica 2013, 51, 191-201. [CrossRef]

43. Clark, A.J.J.; Landolt, W.; Bucher, J.B.B.; Strasser, R.J.J. Beech (Fagus sylvatica) response to ozone exposure assessed with a chlorophyll a fluorescence performance index. Environ. Pollut. 2000, 109, 501-507. [CrossRef]

44. Semida, W.M.; Abd El-mageed, T.A.; Abdelkhalik, A.; Hemida, K.A.; Abdurrahman, H.A.; Howladar, S.M.; Leilah, A.A.A.; Rady, M.O.A. Selenium Modulates Antioxidant Activity, Osmoprotectants, and Photosynthetic Efficiency of Onion under Saline. Agronomy 2021, 11, 855. [CrossRef]

45. Rady, M.M.; Taha, R.S.; Semida, W.M.; Alharby, H.F. Modulation of salt stress effects on vicia faba 1. plants grown on a reclaimed-saline soil by salicylic acid application. Rom. Agric. Res. 2017, 34, 175-185.

46. AOAC. Official Methods of Analysis, 17th ed.; The Association of Official Analytical Chemists: Gaithersburg, MD, USA, 2000; ISBN 0935584676.

47. Michael, A.M. Irrigation Theory and Practice-2Nd Edn: Theory and Practice; Vikas Publishing House: Delhi, India, 2009.

48. Quampah, A.; Ren-Ming, W.; Shamsi, I.H.; Jilani, G.; Zhang, Q.; Hua, S.; Xu, H. Improving water productivity by potassium application in various rice genotypes. Int. J. Agric. Biol. 2011, 13, 9-17.

49. Abd El-Mageed, T.A.; El-Sherif, A.M.A.; Abd El-Mageed, S.A.; Abdou, N.M. A novel compost alleviate drought stress for sugar beet production grown in Cd-contaminated saline soil. Agric. Water Manag. 2019, 226, 105831. [CrossRef]

50. Desoky, E.M.; Elrys, A.S.; Mansour, E.; Eid, R.S.M.; Selem, E.; Rady, M.M.; Ali, E.F.; Mersal, G.A.M.; Semida, W.M. Application of biostimulants promotes growth and productivity by fortifying the antioxidant machinery and suppressing oxidative stress in faba bean under various abiotic stresses. Sci. Hortic. 2021, 288, 110340. [CrossRef]

51. Abid, M.; Tian, Z.; Ata-Ul-Karim, S.T.; Cui, Y.; Liu, Y.; Zahoor, R.; Dai, T. Nitrogen nutrition improves the potential of wheat (Triticum aestivum L.) to alleviate the effects of drought stress during vegetative growth periods. Front. Plant Sci. 2016, 7, 981. [CrossRef]

52. Zaman, N.K.; Abdullah, M.Y.; Othman, S.; Zaman, N.K. Growth and physiological performance of aerobic and lowland rice as affected by water stress at selected growth stages. Rice Sci. 2018, 25, 82-93. [CrossRef]

53. Anjum, S.A.; Xie, X.; Wang, L.; Saleem, M.F.; Man, C.; Lei, W. Morphological, physiological and biochemical responses of plants to drought stress. Afr. J. Agric. Res. 2011, 6, 2026-2032. [CrossRef]

54. Badal, E.; El-Mageed, T.A.A.A.; Buesa, I.; Guerra, D.; Bonet, L.; Intrigliolo, D.S. Moderate plant water stress reduces fruit drop of "Rojo Brillante" persimmon (Diospyros kaki) in a Mediterranean climate. Agric. Water Manag. 2013, 119, 154-160. [CrossRef]

55. Belal, H.E.E.; Rady, M.M.; Gadallah, F.M.; Semida, W.M. Application in two methods elevates drought tolerance by increasing antioxidant defense system and reducing oxidative stress biomarkers in solanum lycopersicum plant. Fayoum J. Agric. Res. Dev. 2020, 34, 130-147. [CrossRef]

56. Abd El-mageed, T.A.; Abdelkhalik, A.; Abd El-mageed, S.A.; Semida, W.M. Co-composted Poultry Litter Biochar Enhanced Soil Quality and Eggplant Productivity Under Different Irrigation Regimes. J. Soil Sci. Plant Nutr. 2021, 1-17. [CrossRef]

57. Abd El-mageed, T.A.; Rady, M.M.; Taha, R.S.; Abd El Azeam, S.; Simpson, C.R.; Semida, W.M. Effects of integrated use of residual sulfur-enhanced biochar with effective microorganisms on soil properties, plant growth and short-term productivity of Capsicum annuum under salt stress. Sci. Hortic. 2020, 261, 108930. [CrossRef] 
58. Semida, W.M.; El-mageed, T.A.A.; Abdalla, R.M.; Hemida, K.A.; Howladar, S.M.; Leilah, A.A.A.; Rady, M.O.A. Sequential Antioxidants Foliar Application Can Alleviate Negative Consequences of Salinity Stress in Vicia faba L. Plants 2021, 10, 914. [CrossRef]

59. Parasuraman, P. Integrated nitrogen management in rice (Oryza sativa) through split application of fertilizers at different levels with green manure. Mysore J. Agric. Sci. 2005, 39, 90-94.

60. Sandhu, S.S.; Mahal, S.S.; Vashist, K.K.; Buttar, G.S.; Brar, A.S.; Singh, M. Crop and water productivity of bed transplanted rice as influenced by various levels of nitrogen and irrigation in northwest India. Agric. Water Manag. 2012, 104, 32-39. [CrossRef]

61. Jiao, J.; Shi, K.; Li, P.; Sun, Z.; Chang, D.; Shen, X.; Xu, L. Assessing of an irrigation and fertilization practice for improving rice production in the Taihu Lake region (China). Agric. Water Manag. 2018, 201, 91-98. [CrossRef]

62. Kruzhilin, I.P.; Doubenok, N.N.; Ganiev, M.A.; Abdou, N.M.; Melikhov, V.V.; Bolotin, A.G.; Rodin, K.A. Water-saving technology of drip irrigated aerobic rice cultivation. ISVESTIYA 2015, 3, 47-56.

63. Chaturvedi, I. Effect of nitrogen fertilizers on growth, yield and quality of hybrid rice (Oryza sativa). J. Cent. Eur. Agric. 2005, $6,611-618$.

64. Singh, H.; Verma, A.; Ansari, M.W.; Shukla, A. Physiological response of rice (Oryza sativa L.) genotypes to elevated nitrogen applied under field conditions. Plant. Signal. Behav. 2014, 9, 1-8. [CrossRef]

65. Semida, W.M.; El-Mageed, T.A.A.; Mohamed, S.E.; El-Sawah, N.A. Combined effect of deficit irrigation and foliar-applied salicylic acid on physiological responses, yield, and water-use efficiency of onion plants in saline calcareous soil. Arch. Agron. Soil Sci. 2017, 63, 1227-1239. [CrossRef]

66. Abd El-Mageed, T.A.; Semida, W.M. Effect of deficit irrigation and growing seasons on plant water status, fruit yield and water use efficiency of squash under saline soil. Sci. Hortic. 2015, 186, 89-100. [CrossRef]

67. Abd El-Mageed, T.A.; Semida, W.M.; Taha, R.S.; Rady, M.M. Effect of summer-fall deficit irrigation on morpho-physiological, anatomical responses, fruit yield and water use efficiency of cucumber under salt affected soil. Sci. Hortic. 2018, 237, 148-155. [CrossRef]

68. Mannan, M.A.; Bhuiya, M.S.U.; Akhand, M.I.M.; Saman, M.M. Growth and yield of basmati and traditional aromatic rice as influenced by water stress and nitrogen level. J. Sci. Found. 2012, 10, 52-62. [CrossRef]

69. Abo Soliman, M.S.M.; Ghanem, S.A.; Abd El-Hafez, S.A.; El-Mowelhi, N. Effect of irrigation regimes and nitrogen levels on rice production and nitrogen losses under title drainage. Minist. Agric. L Reclam. Agric. Res. 1990, 1, 14-15.

70. Tuong, T.P.; Bouman, B.A.M. Rice Production in Water Scarce Environments. In Water Productivity in Agriculture: Limits and Opportunities for Improvement; Kijne, J.W., Barker, R., Molden, D., Eds.; CABI Publishing: Wallingford, UK, 2003. 